\title{
Agronomic Performance of Kenyan Orange Fleshed Sweet Potato Varieties
}

\author{
Heritier Kambale Mbusa ${ }^{1,2}$, Kahiu Ngugi ${ }^{2}$, Florence M. Olubayo ${ }^{2}$, Benjamin Musembi Kivuva ${ }^{3}$, James W. \\ Muthomi $^{2} \&$ Felister M. Nzuve ${ }^{2}$ \\ ${ }^{1}$ Faculty of Agricultural Sciences, Université Catholique du Graben, Butembo, Democratic Republic of the \\ Congo \\ ${ }^{2}$ Department of Plant Science and Crop Protection, Faculty of Agriculture, University of Nairobi, Republic of \\ Kenya \\ ${ }^{3}$ Kenya Agricultural and Livestock Research Organization (KALRO), Katumani station, Republic of Kenya \\ Correspondence: Heritier Kambale Mbusa, Faculty of Agricultural Sciences, Université Catholique du Graben, \\ P.O. box 29 Butembo, Nord-Kivu, D.R. Congo. Tel: 254-739-952-535. E-mail: heritiermbaf@ gmail.com
}

Received: February 10, $2018 \quad$ Accepted: March 2, $2018 \quad$ Online Published: June 6, 2018

doi:10.5539/jps.v7n2p11

URL: https://doi.org/10.5539/jps.v7n2p11

\begin{abstract}
Sweet potato is one of the most important staple crops in Sub-Sahara Africa because of its supply of carbohydrates, vitamin A and C, fiber, iron, potassium and protein. The objective of this study was to determine phenotypic variation in diverse sweetpotato varieties for marketable roots, fresh root yield, fresh biomass weight, harvest index, beta carotene content and root dry matter content. Twenty five sweet potato genotypes were evaluated at two sites in two seasons in Kenya using a randomized complete block design of three replications. The results indicated that there were highly significantly variations for genotypes and sites for all the traits studied. There were no significant differences for genotype $\mathrm{x}$ site $\mathrm{x}$ season effects for the traits except for the number of marketable roots and fresh root yield. The mean fresh root was $32.19 \mathrm{t} / \mathrm{ha}$, with the genotype Ininda expressing the highest fresh root yield of 54.79 t/ha. Genotypes, Naspot 13, Ejumula, Kabode, Vitaa and Tio-Joe gave the highest beta carotene content ranging between 11.830 and $10.040 \mathrm{mg} / 100 \mathrm{~g}$; with a mean of 5.384 $\mathrm{mg} / 100 \mathrm{~g}$. The mean root dry matter content was $24.84 \%$ with clones Amelia and Melinda showing the highest and lowest root dry matter content of 30.62 and $16.52 \%$ respectively. Ten genotypes including Ininda, Erica, Jane, Naspot 13, Ejumula, Kabode, Vitaa, Tio-Joe, Amelia and Mayai were recommended as potential parents for sweet potato breeding program in Kenya.
\end{abstract}

Keywords: beta carotene content, genotypes, phenotypic variation, sweet potato

\section{Introduction}

Sweet potato, the seventh most important staple food globally, produces more edible energy per hectare per day than wheat, cassava or rice (Woolfe, 1992). Orange fleshed sweet potato varieties provide carotene, a precursor for vitamin A, that reduces vitamin A deficiency (VAD) in children and lactating mothers (Low et al., 2001). The crop is consumed as fresh roots or as leaves and is also processed into animal feed, starch, flour, candy and alcohol (Chiona, 2009). According to Woolfe (1992) sweet potato can be substituted for wheat in bread, cereals and in many tasty, nutritious recipes.

Unlike cereals, sweet potato is harvested all year-round providing a long term solution for vitamin A deficiency (Mwanga \& Ssemakula, 2011). The crop is adaptable to diverse environments because it tolerates high temperatures, low fertility soils, can grow in areas with low annual rainfall and is easy to propagate (Stathers et al., 2013).

Despite these advantages, sweet potato production is hampered by constraints, such as low yields resulting from lack of improved planting materials, poor root storage, weevil damage and unfavourable root shape (Belehu, 2003). In addition, most Kenyan sweet potato varieties are white-fleshed, therefore lacking in the essential beta carotene content (Low et al., 2017)

Orange fleshed sweet potatoes offer an alternative means of addressing vitamin A deficiency because they contain high levels of beta carotene. It has been shown that a regular intake of about $100 \mathrm{gm}$ of orange fleshed 
sweet potato roots per day provides the recommended daily amount of vitamin A for children, effectively protecting them from blindness (Mukherjee \& Ilangantileke, 2002). This study sought to identify the phenotypic variation for yield, yield components, beta carotene content and dry matter content of orange fleshed sweet potato varieties grown in Kenya.

\section{Materials and Methods}

\subsection{Experimental Sites}

Field experiments were conducted at two sites, namely, KALRO-Kiboko and Kabete field station of the University of Nairobi. The KALRO-Kiboko research station ( $2^{\circ} 15^{\prime} \mathrm{S}, 37^{\circ} 45^{\prime} \mathrm{E}$ and $993 \mathrm{~m}$ asl) is located in Agro-ecological Zone 5, in Makueni county, $187 \mathrm{~km}$ East of Nairobi. The station receives bimodal precipitation with short rains season beginning in late October to December $(330 \mathrm{~mm}$ ) and long rains from March to May (230 $\mathrm{mm}$ ). The average annual temperature is $24^{\circ} \mathrm{C}$. The soil is rhodic ferrosols (Kivuva, 2013). Kabete Field Station of University of Nairobi $\left(1^{\circ} 15^{\prime} \mathrm{S}, 36^{\circ} 44^{\prime} \mathrm{E}\right.$ and $1930 \mathrm{~m}$ asl) is located in Nairobi county at about $15 \mathrm{~km}$ to Nairobi city and receives binomial rainfall with the short rain season beginning in October to December and the long rain season occurring between March to May. The annual rainfall is $1006 \mathrm{~mm}$ and the overage annual temperature is $18{ }^{\circ} \mathrm{C}$. The soil is well drained, deep, darkish brown to dark red and is humic nitrisol type (Onyango et al., 2012)

\subsection{Planting Materials}

Twenty five varieties varying in yield and in beta carotene content as shown in Table 1 were selected for agronomic evaluation in two locations and seasons.

Table 1. Sweet potato clones, local names, origin, flesh color and skin color evaluated at Kiboko and Kabete

\begin{tabular}{lllll}
\hline Name & Origin & Flesh color & Skin color & References \\
\hline Kenspot 5 & Kenya & Orange & Purple & Tumwegamire et al. (2014) \\
Mayai & Tanzania & Yellow & Brownish orange & Tumwegamire et al. (2014) \\
Kakamega & Kenya & Intermediate orange & Purple & Tumwegamire et al. (2014) \\
Lourdes & Mozambique & Intermediate orange & Cream & Tumwegamire et al. (2014) \\
Tio Joe & Mozambique & Dark orange & Light purple & Tumwegamire et al. (2014 \\
Naspot 1 & Uganda & Cream & Purple red & Mwanga et al. (2003) \\
Amelia & Mozambique & Orange & Pink & Kapinga et al. (2010) \\
Ejumula & Uganda & Deep orange & Purple red & Mwanga et al. (2003) \\
Naspot 2 & Uganda & Cream & Cream & Kapinga et al. (2010) \\
Ininda & Mozambique & Orange & Purple red & Kapinga et al. (2010) \\
Melinda & Mozambique & Light orange & Purple red & Kapinga et al. (2010) \\
Kabode & Uganda & Deep orange & Purple red & Kapinga et al. (2010) \\
Cecilia & Mozambique & Pale orange & Cream & Kapinga et al. (2010) \\
Naspot 8 & Uganda & Intermediate orange & Brown & Mwanga et al. (2003) \\
Jane & Kenya & Intermediate orange & Cream & Kapinga et al. (2010) \\
Erica & Kenya & Yellow orange & Purple red & Kapinga et al. (2010) \\
Sumaia & Uganda & Deep orange & Purple red & Tumwegamire et al. (2014) \\
Gweri & Uganda & Intermediate orange & Purple red & Mwanga et al. (2003) \\
Naspot 12 & Uganda & Intermediate orange & Cream & Tumwegamire et al. (2014) \\
Delvia & Mozambique & Orange & Purple red & Tumwegamire et al. (2014) \\
Vitaa & Uganda & Deep orange & Purple red & Tumwegamire et al. (2014) \\
Irene & Mozambique & Orange & Purple red & Tumwegamire et al. (2014) \\
Naspot 13 & Uganda & Deep orange & Cream & Tumwegamire et al. (2014) \\
Kenspot 4 & Kenya & Orange & Cream & Tumwegamire et al. (2014) \\
Tanzania & Tanzania & Yellow & Brown & Mwanga et al. (2003) \\
\hline & & & &
\end{tabular}

\subsection{Experimental Design}

The two trials were laid out in field at KARI-Kiboko and Kabete Field Station between July and November 2016, and a second set of trials was conducted in the same sites between November 2016 and March 2017. All the experiments were laid out in a randomized complete block design (RCBD) with three replications. Each replication was composed of 25 plots corresponding to 25 clones used as treatments. All clones were planted in a quadruple row of $1.2 \mathrm{~m}$ long for four plants per genotype per row at spacing of $30 \mathrm{~cm}$ within the row and $90 \mathrm{~cm}$ 
between rows. The plot had $4.32 \mathrm{~m}^{2}(3.6 \mathrm{~m} \times 1.2 \mathrm{~m})$ as dimensions.

Diammonium phosphate (DAP) fertilizer was applied two weeks after the time of sowing at a rate of $115 \mathrm{~kg} / \mathrm{ha}$. Cut worms were controlled with insecticide, IMAX 200SC which was applied every week until the establishment of the crop at a rate of $10 \mathrm{ml}$ in twenty liters of water. The clones were regularly irrigated to maintain growth and weeded by hand when it was necessary to do so.

\subsection{Data Collection}

Fresh roots were harvested 120 days after planting using hand hoe and data were collected on eight plants within a harvested plot of $2.16 \mathrm{~m}^{2}$. Yield and yield components were measured as follows: total number of marketable roots per plant (NMR) was determined from counting roots weighing between 100 and 500 grams. Fresh root yield (FRY) was measured in kilograms as the combined harvested root on each plot using a balancing scale and the recorded weight per plot unit was extrapolated to tonnes per hectare basis (tonnes/ha). Fresh biomass weight (WB) was measured in kilograms as the harvested root together with fresh cut vines per plot and was extrapolated to tonnes per hectare (t/ha). Harvest index (HI) was estimated as the ratio of the fresh root yield and fresh biomass weight and expressed in percentage. Root dry matter content (RDMC) was determined as the percent of the ratio of root dry weight and fresh root weight. Beta carotene content (BCC) was estimated using the method described by Burgos et al. (2014) in $\mathrm{mg}$ per $100 \mathrm{gm}$ of fresh weight.

\subsection{Data Analysis}

The data for number of marketable roots (NMR), fresh root yield (FRY), fresh biomass weight (WB), harvest index (HI), beta carotene content (BCC) and root dry matter content (DMC) across the two sites and seasons were subjected to the analysis of variance using GENSTAT $15^{\text {th }}$ edition. Means were compares with the Fisher's protected least significant differences (LSD) test at 5\% significance level. Pearson correlation coefficient analysis was done to determine the association between the traits studied.

\section{Result}

\subsection{Field Trial}

Table 2 presents the mean squares of the yield components in the twenty five sweet potato genotypes across the two sites and in two seasons. The combined ANOVA showed highly significant effects for genotypes and for sites in all the traits $(\mathrm{p}<0.001)$. Seasons, showed highly significant differences for number of marketable roots, fresh biomass weight, and harvest index and beta carotene content $(\mathrm{p}<0.001)$, whereas no significant differences were observed for fresh root yield and dry matter content $(p>0.05)$. There were no significant differences for the genotype $\mathrm{x}$ sites $\mathrm{x}$ season effect for many traits again except for weight of marketable roots (significant difference, $\mathrm{p}<0.05$ ), fresh root yield and biomass weight (very high significant difference, $\mathrm{p}<$ $0.001)$.

Table 2. Mean squares for yield and yield related parameters and nutrient contents among twenty five sweet potato genotypes across sites and seasons

\begin{tabular}{llllllll}
\hline Source of variation & d.f. & NMR & FRY & WB & HI & BCC & DMC \\
\hline Blocks & 2 & 0.21 & 1281 & 290 & 2295 & 0.13 & 3.57 \\
Genotypes & 24 & $1.68^{* * *}$ & $932^{* * *}$ & $1937^{* * *}$ & $563^{* * *}$ & $174.81^{* * *}$ & $212.96^{* * *}$ \\
Sites & 1 & $99.67^{* * *}$ & $132775^{* * *}$ & $170675^{* * *}$ & $75913^{* * *}$ & $2.51^{* * *}$ & $367.13^{* * *}$ \\
Seasons & 1 & $6.49^{* * *}$ & $18^{\mathrm{ns}}$ & $19414^{* * *}$ & $1015^{* * *}$ & $0.52^{* *}$ & $0.55^{\mathrm{ns}}$ \\
Genotypes x Sites & 24 & $1.87^{* * *}$ & $774^{* * *}$ & $1106^{* * *}$ & $369^{* * *}$ & $0.09^{\mathrm{ns}}$ & $15.68^{* * *}$ \\
Genotypes x Seasons & 24 & $0.38^{\mathrm{ns}}$ & $469^{* * *}$ & $562^{* * *}$ & $225^{* * *}$ & $0.07^{\mathrm{ns}}$ & $0.16^{\mathrm{ns}}$ \\
Sites x Seasons & 1 & $0.76^{\mathrm{ns}}$ & $12987^{* * *}$ & $79677^{* * *}$ & $2^{\mathrm{ns}}$ & $0.05^{\mathrm{ns}}$ & $0.04^{\mathrm{ns}}$ \\
Genotypes x Sites x Seasons & 24 & $0.52^{*}$ & $440^{* * *}$ & $692^{* * *}$ & $116^{\mathrm{ns}}$ & $0.02^{\mathrm{ns}}$ & $0.72^{\mathrm{ns}}$ \\
Error & 198 & 0.28 & 60 & 243 & 82 & 0.06 & 0.73 \\
Total & 299 & & & & & & \\
\hline
\end{tabular}

Note: $* * * * *, *$ and ${ }^{\mathrm{ns}}=$ very high and high significant and no significant differences; d.f. $=$ degrees of freedom, NMR $=$ number of marketable roots; $\mathrm{FRY}=$ fresh root yield; $\mathrm{WB}=$ weight of biomass; $\mathrm{HI}=$ harvest index; $\mathrm{BCC}=$ beta carotene content and $\mathrm{DMC}=\mathrm{dry}$ matter content.

\subsection{Phenotypic Performance of Sweet Potato Genotypes}

The results of the means for all variables are presented in Tables 3 and 4. For the number of marketable roots, genotypes, Ininda (2.6), Sumaia (2.3) Naspot12 (2.1) and Erica (2.0) had the highest number of marketable roots 
(NMR). The lowest number of marketable roots was given by genotypes, Gweri, Naspot 2 and Kakamega with 0.8, 1.1 and 1.2 values respectively (Table 4). For fresh root yield (FRY), genotypes, Ininda (54.79 t/ha), Erica $(46.70 \mathrm{t} / \mathrm{ha})$ and Jane $(45.03 \mathrm{t} / \mathrm{ha})$ had the highest root yield whereas clones, Kakamega (19.10 t/ha), Gweri $(17.63 \mathrm{t} / \mathrm{ha})$ and Naspot 2 (20.00 t/ha) had the lowest root yield (Table 4). With regard to fresh biomass weight (WB), genotypes, Ininda (94.56 t/ha), Naspot 12 (85.26 t/ha), Erica (83.65 t/ha) and Jane (79.01 t/ha) had the highest biomass weight whereas genotypes, Amelia, Kakamega and Ejumula had the lowest biomass weight with $41.51 \mathrm{t} / \mathrm{ha}, 47.33 \mathrm{t} / \mathrm{ha}$ and $50.01 \mathrm{t} / \mathrm{ha}$ values respectively. The highest average harvest index was recorded by genotypes Amelia (52.2 \%), Ininda (51.0 \%), Ejumula and Vitaa (49.3\%), Naspot8 (48.3\%) and Erica (47.4 \%) but genotypes, Gweri (20.4\%), Naspot1 (32.2\%), and Kakamega (34.1\%) had the lowest HI. With respect to the sites, the genotypes grown at KALRO-Kiboko had high values for most of the yield and yield parameters compared to these grown at Kabete (Table 3)

Genotypes, Naspot13, Ejumula, Kabode, Vitaa, Tio-Joe and Lourdes had the highest beta carotene concentration that ranged between 9.853 and $11.830 \mathrm{mg} / 100 \mathrm{~g}$. but genotypes, Naspot2, Naspot1, Mayai, Tanzania and Gweri had the lowest beta carotene content (Table 4). With regard to dry matter content, clones Naspot1, Amelia, Ejumula, Gweri, Naspot12, Kenspot4 and Tanzania had the highest dry matter content that ranged between 27.54 and 29.13\%. Genotypes, Erica, Melinda, Lourdes, Sumaia and Ininda had the lowest dry matter content that ranged between 16.54 and $21.88 \%$. Genotypes grown at Kabete had higher beta carotene content than those grown at KALRO-Kiboko with 5.476 and $5.293 \mathrm{mg} / 100 \mathrm{~g}$ values respectively. For dry matter content, clones from KALRO-Kiboko had higher dry matter concentration than those at Kabete Field Station (Table 3).

Table 3. Mean performance for the number of marketable roots, fresh root yield and fresh biomass weight among sites across seasons

\begin{tabular}{lllllll}
\hline Sites & NMR $\left(\mathrm{n}^{\circ}\right)$ & FRY $\left(\mathrm{t} . h a^{-1}\right)$ & WB $\left(\mathrm{t} . \mathrm{ha}^{-1}\right)$ & HI $(\%)$ & BCC $(\mathrm{mg} / 100 \mathrm{~g})$ & DMC $(\%)$ \\
\hline Kabete & 1.1 & 11.15 & 40.94 & 27.07 & 5.476 & 23.72 \\
KALRO Kiboko & 2.3 & 53.22 & 88.64 & 58.88 & 5.293 & 25.93 \\
\hline MEAN & 1.7 & 32.19 & 64.79 & 42.97 & 5.384 & 24.83 \\
LSD & 0.12 & 1.76 & 3.55 & 2.07 & 0.055 & 0.19 \\
C.V & 31.71 & 24.05 & 24.04 & 21.11 & 4.460 & 3.45 \\
\hline
\end{tabular}

L.S.D. = Least significant difference; C.V. = Coefficient of variation; NMR= number of marketable roots per plant; NUR=number of unmarketable roots per plant; NSR=number of storage roots per plant, FRY=fresh root yield $(t / h a)$ and $W B=$ fresh biomass weight $(t / h a)$ $\mathrm{BCC}=$ beta carotene content $(\mathrm{mg} / 100 \mathrm{~g})$ and $\mathrm{DMC}=$ dry matter content $(\%)$. 
Table 4. Mean performance for number of marketable roots, fresh root yield and fresh biomass weight among twenty five sweet potato genotypes across sites and seasons

\begin{tabular}{lllllll}
\hline Genotype & NMR $\left(\mathrm{n}^{\circ}\right)$ & FRY $(\mathrm{t} / \mathrm{ha})$ & WB $(\mathrm{t} / \mathrm{ha})$ & HI $(\%)$ & BCC $(\mathrm{mg} / 100 \mathrm{~g})$ & DMC $(\%)$ \\
\hline Amelia & 2.0 & 24.05 & 42.29 & 53.11 & 4.261 & 30.62 \\
Cecilia & 1.7 & 29.88 & 56.00 & 43.77 & 5.776 & 23.45 \\
Delvia & 1.7 & 37.35 & 75.06 & 42.3 & 4.671 & 27.12 \\
Ejumula & 1.3 & 28.02 & 51.06 & 49.47 & 11.209 & 29.83 \\
Erica & 2.0 & 46.56 & 83.65 & 47.37 & 1.648 & 16.88 \\
Gweri & 0.8 & 17.63 & 61.17 & 20.45 & 0.864 & 29.57 \\
Ininda & 2.6 & 54.79 & 94.56 & 50.97 & 4.945 & 22.52 \\
Irene & 1.8 & 37.32 & 65.40 & 48.73 & 7.832 & 21.78 \\
Jane & 1.4 & 45.03 & 79.01 & 45.04 & 4.956 & 17.43 \\
Kabode & 1.8 & 25.74 & 50.94 & 43.78 & 10.785 & 29.05 \\
Kakamega & 1.2 & 19.10 & 47.33 & 34.14 & 3.537 & 27.37 \\
Kenspot 4 & 1.7 & 33.79 & 71.05 & 38.42 & 3.739 & 28.36 \\
Kenspot 5 & 1.7 & 29.97 & 53.00 & 42.22 & 5.115 & 27.13 \\
Lourdes & 1.7 & 34.63 & 68.24 & 39.37 & 9.853 & 22.26 \\
Mayai & 1.8 & 27.45 & 56.60 & 44.70 & 0.000 & 29.73 \\
Melinda & 1.6 & 36.95 & 66.66 & 46.66 & 4.993 & 16.52 \\
Naspot 1 & 1.6 & 25.38 & 69.59 & 33.58 & 0.000 & 29.02 \\
Naspot 12 & 2.1 & 38.33 & 85.26 & 44.11 & 7.913 & 24.08 \\
Naspot 13 & 1.3 & 23.26 & 59.45 & 36.93 & 11.83 & 22.99 \\
Naspot 2 & 1.1 & 23.54 & 53.34 & 41.02 & 0.000 & 23.62 \\
Naspot 8 & 1.6 & 26.61 & 59.13 & 48.52 & 2.636 & 26.33 \\
Sumaia & 2.3 & 32.18 & 65.10 & 43.02 & 7.062 & 21.90 \\
Tanzania & 1.7 & 41.35 & 71.08 & 48.26 & 0.446 & 28.75 \\
Tio Joe & 1.9 & 33.96 & 74.23 & 40.32 & 10.040 & 21.9 \\
Vitaa & 1.7 & 31.81 & 60.53 & 48.09 & 10.501 & 22.47 \\
\hline MEAN & 1.70 & 32.19 & 64.79 & 42.97 & 5.384 & 24.83 \\
LSD & 0.43 & 6.23 & 12.54 & 7.30 & 0.193 & 0.69 \\
C.V. (\%) & 31.71 & 24.05 & 24.04 & 21.11 & 4.460 & 3.45 \\
\hline
\end{tabular}

L.S.D. = Least significant difference; C.V. = Coefficient of variation; NMR= number of marketable roots per plant; NUR=number of unmarketable roots per plant; NSR=number of storage roots per plant, FRY=fresh root yield $(t / h a)$ and $\mathrm{WB}=$ fresh biomass weight $(\mathrm{t} / \mathrm{ha})$ $\mathrm{BCC}=$ beta carotene content $(\mathrm{mg} / 100 \mathrm{~g})$ and $\mathrm{DMC}=$ dry matter content $(\%)$.

\subsection{Phenotypic Correlation between Traits Studied}

Fresh root yield was positively significantly correlated with all the traits $(r=0.821$ for HI, $r=0.750$ for NMR and $\mathrm{r}=0.875$ for $\mathrm{WB}$ ) but was negatively insignificantly correlated with beta carotene and dry matter content ( $\mathrm{r}$ $=-0.031$ and $\mathrm{r}=0.033$ ), respectively (Table 5). There was negatively significant association between beta carotene and root dry matter content $(\mathrm{r}=-0.199)$ (Table 5). 
Table 5. Combined table showing correlation between parameters for twenty five sweet potato genotypes for two sites

\begin{tabular}{llllll}
\hline Traits & HI & NMR & WB & FRY & BCC \\
\hline NMR & $\mathbf{0 . 7 3 6}^{*}$ & & & & \\
WB & $\mathbf{0 . 5 3 8}^{*}$ & $\mathbf{0 . 5 9 1}^{*}$ & & & \\
FRY & $\mathbf{0 . 8 2 1}^{*}$ & $\mathbf{0 . 7 5 0}^{*}$ & $\mathbf{0 . 8 7 5}^{*}$ & & \\
BCC & $0.041^{\text {ns }}$ & $0.064^{\text {ns }}$ & $-0.031^{\text {ns }}$ & $-0.007^{\text {ns }}$ & \\
DMC & $0.117^{*}$ & $0.072^{\text {ns }}$ & $0.018^{\text {ns }}$ & $0.033^{\text {ns }}$ & $-0.199^{*}$ \\
\hline
\end{tabular}

${ }^{\mathrm{ns}}$ and $*=$ no significant and significant correlation; $\mathrm{NMR}=$ number of marketable roots; $\mathrm{FRY}=$ fresh root yield; $\mathrm{WB}=$ weight of biomass; $\mathrm{HI}=$ harvest index; $\mathrm{BCC}=$ beta carotene content and $\mathrm{DMC}=$ dry matter content.

\section{Discussion}

There were significant differences among the genotypes, sites, seasons, site $\mathrm{x}$ season effect and genotype $\mathrm{x}$ site $\mathrm{x}$ seasons in respect to yield and yield components (Table 2). Phenotypic variability in sweet potato nutrient contents was observed among genotypes and site (Table 2). The number of marketable roots varied from 0.80 to 2.60 roots per plant. Fresh root yield varied from $54.79 \mathrm{t} / \mathrm{ha}$ to17.63 t/ha while biomass weight varied from 94.56 to 42.29 t/ha. Harvest index varied from $53.11 \%$ to $20.45 \%$ (Table 4). The average root yield at KALRO-Kiboko was higher than at Kabete at 44.47 t/ha and 11.15 t/ha respectively (Table 3 ). Variability among genotypes for marketable root number, fresh root yield and biomass weight might have been due to both genetic and environmental factors. Vinaja \& Babu (2006) and Yadeta et al. (2011) reported that while variability for most of the yield components in sweet potato is attributable to genetic factors, environmental factors do play a part. Hafekamp (1988) indicated that rainfall, temperature, light and soil nutrients are the main factors affecting sweet potato growth and productivity. During the time these trials were conducted, environmental conditions were favourable at KALRO-Kiboko than at Kabete; because there was supplemental irrigation at Kiboko which was not the case at Kabete. At KALRO-Kiboko the trials were irrigated three times per week at seedling stage but irrigated once per week thirty days after planting. Lower performance by all genotypes at Kabete compared to those grown at KALRO-Kiboko may be explained by the temperature factor. Meteorological data from the two stations during the experimentation period showed that Kabete was characterized by cold temperatures of $22.5{ }^{\circ} \mathrm{C}$ and $13{ }^{\circ} \mathrm{C}$ day and night temperature respectively, whereas Kiboko had warmer temperatures with an average day and night temperature of $31.2{ }^{\circ} \mathrm{C}$ and $17.8^{\circ} \mathrm{C}$ respectively. Sedioka (1964) stated, sweet potato yields were five to six times higher when day and night temperature of $25^{\circ} \mathrm{C}$ and $20^{\circ} \mathrm{C}$ were observed than at $15^{\circ} \mathrm{C}$ and $13{ }^{\circ} \mathrm{C}$ day and night temperatures occurred respectively. Mandal (2006), also reported that low night temperatures of less than $20^{\circ} \mathrm{C}$ negatively affected tuber formation and development, but day temperatures of between $25^{\circ} \mathrm{C}$ to $30^{\circ} \mathrm{C}$ were ideal for more tuber formation and development. In addition, altitude influences yield and yield components in sweet potato., KALRO-Kiboko is situated at a lower altitude of $993 \mathrm{~m}$ above sea level whereas Kabete has an altitude of 1930 m above sea level. Lower yield and yield components at Kabete may be have been obtained because as reported elsewhere, lower temperatures are expected at higher altitudes compared to higher temperatures of lower elevation at KALRO-Kiboko. Negeve et al. (1992) observed that in the tropics, sweet potato yields declined with increasing altitudes as did the number of roots and the proportion of marketable roots. Negeve et al. (1992) also observed that the increasing altitude delays sweet potato maturity and Lebot (2009) reported that sweet potato root yield and yield components could be determined by the length of the growing period. These observations were also supported by Tairo et al. (2008) who observed that the number of storage roots, weight of storage roots, fresh weight per plant and dry matter content of sweet potatoes differed significantly among and within agro-ecological zones. In the present study, in addition to genotypic variability, there was variations due to sites and seasons which might have significantly influenced yield and yield components.

No significant interaction of genotype $\mathrm{x}$ site $\mathrm{x}$ season was recorded for beta carotene and root dry matter content though the genotypic effect were significant as shown in (Table 2). This indicated that variability in beta carotene and root dry matter was not largely influenced by the environmental effects of sites and seasons but was likely to be genetically determined and the values scored irrespective of site or season could be a basis for selection. High beta carotene contents of between 9.853 and $11.830 \mathrm{mg} / 100 \mathrm{~g}$ were shown by clones, Tio-Joe, Vitaa, Kabode, Ejumula and Naspot13 (Table 4). In contrast, clones, Naspot 1, Naspot 2, Mayai, Tanzania and Gweri had low beta carotene concentrations (Table 4) and the root dry matter content varied from 30.62 to $16.56 \%$ (Table 4). The overall beta carotene content was $5.321 \mathrm{mg} / 100 \mathrm{~g}$ at Kabete which was higher than that at KALRO-Kiboko 
of $5.147 \mathrm{mg} / 100 \mathrm{~g}$ (Table 3). There is a possibility that the day and night temperatures observed at Kabete may have contributed to the accumulation of high beta carotene content over and above the genotypic effect. Genotypes grown at KALRO-Kiboko exhibited the highest mean root dry matter content of $25.94 \%$ while those grown at Kabete showed a mean root dry matter of $23.72 \%$ (Table 3) again showing how critical the environmental factors are. Therefore, the wide variability shown by genotypes evaluated here for beta carotene and dry matter content might be mainly due to genetic variance than due to environmental variance but environmental effects for these parameters though small did affect their performance. This suggestion is supported by the works of Dominguaz (1976) who reported that sweet potato beta carotene and root dry matter contents are genetically controlled traits. In this study the highest beta carotene content was observed from the deep to orange fleshed clones, while the white and yellow genotypes yielded the least beta carotene content as also reported by Burgos et al. (2009) and Waniboko \& Ogidi (2014). The latter authors also reported a positive association of beta carotene and orange flesh color in sweet potato. In this study beta carotene content and root dry matter content were negatively correlated. This negative correlation may be associated with the fact that both, beta carotene and root dry matter contents are synthesized inside plastids, chromoplast and amyloplast, respectively. Therefore it is possible that chromoplast and amyloplast may be competing for the same organelles as reported by Cervantes-Flores et al. (2011). In addition, beta carotene content was negatively correlated with fresh root yield (Table 5) indicating that selection of genotypes for high beta carotene and root dry matter contents would result in lower fresh root yield because of their negative association existed between them (Woolfe, 1992; Mbusa et al., 2018).

\section{Conclusion}

Genotypes Ininda, Erica, Jane, Tanzania, Naspot 12, Delvia, Irene and Melinda performed well across sites and seasons. Biomass weight and harvest index were higher in the high yielding sweet potato genotypes. Clones Naspot13, Ejumula, Kabode, Vitaa, Tio-Joe, Lourdes, Irene and Sumaia with a deep orange flesh color had the highest beta carotene content with moderately to high dry matter content. White and yellow fleshed sweet potato genotypes had highest dry matter content. This study showed that genotypes with high yield, high ,beta carotene and dry matter contents and, stable across environments could be selected for These genotypes could be tested further in multiple sites to validate their performance or their use as parental lines in breeding programs in order to improve sweet potato productivity.

\section{Acknowledgements}

This publication was made possible through support provided by the Alliance for a Green Revolution in Africa (AGRA) Grant No 2015 PASS 011. The opinions expressed herein are those of the author(s) and do not necessarily reflect the views of AGRA.

\section{References}

Belehu, T. (2003). Agronomical and physiological factors affecting growth, development and yield of sweet potato in Ethiopia. PhD Thesis. University of Pretoria. 213 p.

Burgos, G., Carpio, R., Sanchez, C., Sosa, P., Espinoza, J., \& Grüneberg, W. (2009). Guide for using the RHS color chart for selecting for high $\beta$-carotene swetpotato. ISTRC, Lima, Peru. Retrieved from A color chart to screen for high $\beta$-carotene in OFSP breeding

Burgos, G., Munoa, L., Sosa, P., Cayhualla, E., Carpio, R., \& Felde, T. Z. (2014). Procedures for chemical analysis of potato and sweet potato at CIP's quality and nutrition laboratory. International Potato Center (CIP). Lima. Peru. 32 p. ISBN 978-92-9060-444-0. 32p. http://dx.doi.org/10.4160/9789290604440

Cervantes-Flores, J. C., Sosinski, B., Pecota, K. V., Mwanga, R. O. M., Catignana, G. L., Truong, V. D., ... Yencho, G. C. (2011). Identification of quantitative trait loci for dry matter, starch, and $\beta$-carotene content in sweetpotato. Journal of Molecular Breeding, 28, 201-216. https://doi.org/10.1007/s11032-010-9474-5

Chiona, M. (2009). Towards enhancement of $\beta$-carotene content of high dry mass sweetpotato genotypes in Zambia. PhD thesis. University of Kwazulu-Natal, Pietermaritzburg, Republic of South Africa. Retrieved from https://books.google.co.ke/books?isbn=1780644205

Dominguaz, P. L. (1976). Feeding of sweetpotato in monogastrics. Roots, tuber and plantains and bananas in animal Feeding. Food and Agriculture Organization of the United Nations, Rome, Italy. 217-233. ISBN 92-5-103138-X. Retrieved from www.fao.org/docrep/003/T0554E/T0554E00.HTM

Hafekamp, M. R. (1988). Environmental factors affecting plant productivity: Achieving efficient use of rangeland resources. Fort Keogh Livestock and Range Research Laboratory, USDA-ARS, Montana State 
University. Retrieved from https://www.oregonstate.edu/dept/eoarc/publication/1987/328

Kapinga, R., Tumwegamire, S., Ndunguru, J., Andrade, M. I., Agili, S., Mwanga, R. O., Laurie, S., \& Dapaah, H. (2010). Catalogue of orange-fleshed sweetpotato varieties for Sub-Saharan Africa. International Potato Center (CIP), Lima, Peru. 40p. ISBN 978-92-9060-383-2. https://doi.org/10.4160/9789290603832

Kivuva, B. (2013). Breeding sweet potato (Ipomoea batatas (L.) Lam) for drought tolerance in Kenya, $\mathrm{PhD}$ Thesis, University of KwaZulu Natal, Republic of South Africa, 198 pages.

Lebot V. (2009). Sweetpotato, In tropical root and tuber crops: cassava, sweet potato, yams and aroids. CAB.

Lebot V. (2009). Tropical root and tuber crops: cassava, sweet potato, yams and aroids. CAB. ISBN 9781845934248.

Low, J., Mwanga, R. O. M., Andrade, M., Carey, E., \& Ball, A. M. (2017). Tackling vitamin A deficiency ith biofortified sweetpotato in Sub-Saharan Africa. Global Food Security, 14(2017) 23-30. https://doi.org/10.1016/j.gfs.2017.01.004

Low, J., Walker, T., \& Hijmans, R. (2001). The potential impact of orange-fleshed sweet potatoes on vitamin A intake in Sub-Saharan Africa. The VITAA Project, vitamin A and orange-fleshed sweetpotatoes in Sub-Saharan Africa, 9-11 May, 2001, Nairobi, Kenya. Retrieved from http://www.cipotato.org/vitaa/Publications/Paper_vitaa.pdf

Mandal, R. C. (2006). Tropical root and tuber crops, Agrobios, India, 360 pages.

Mbusa, H., Ngugi, K., Olubayo, F., Kivuva, B., Muthomi, J., \& Nzuve, F. (2018). The Inheritance of Yield Components and Beta Carotene Content in Sweet Potato. Journal of Agricultural Science, 10(2), 71. http://dx.doi.org/10.5539/jas.v10n2p71

Mukherjee, P. K., \& Ilangantileke, S. (2002). Dietary intervention with orange fleshed sweetpotato (Ipomoea batatas (L.) Lam) to alleviate vitamin A deficiency in South and West Asia. Acta Horticulturae, 583, 205-210. https://doi.org/10.17660/ActaHortic.2002.583.23

Mwanga, R. O. M., \& Gorrettie Ssemakula. (2011). Orange-fleshed sweetpotatoes for food, health and wealth in Uganda. International Journal of Agricultural Sustainability, 9(1), $42-49$. https://doi.org/10.3763/ijas.2010.0546

Mwanga, R. O. M., Odongo, B., Turyamureeba, G., \& Alojo, A. (2003). Release of six sweetpotato cultivars (NASPOT 1 to NASPOT 6) in Uganda. HortScience, 38(3), 475-476.

Negeve, J. M., Hahn, S. K., \& Bouwkamp, J. C. (1992). Effect of altitude and environments on sweet potato yield in Cameroon. Trop. Agr. Trinidad, 69, 43-48.

Onyango, C. M., Harbinson, J., Imungi, J. K., Onwango, R. N., \& Kooten, O. (2012). Effect of nitrogen source, crop maturity stage and storage conditions on phenolic and oxalate contents in vegetable amaranthe (Amaranthus hypochondriacus). Journal of Agricultural Science, 4(7), 2012. https://doi.org/10.5539/jas.v4n7p219

Sekioka, H. (1964). The effect of some environmental factors on the translocation and storage of carbohydrate in the sweet potato, potato and sugar beet: III. Bulletin of the faculty of Agriculture. Kyushu University 21, $131-148$

Stathers, T., Benjamin, M., Katcher, H., Blakenship, J., \& Low, J. (2013). Everything You Ever Wanted to Know about Sweetpotato: Reaching Agents of Change ToT Manual 2: Orange-fleshed sweetpotato and nutrition. International Potato Center, Nairobi, Kenya. vol.2.

Tairo, F., Mneney, E., \& Kullaya, A. (2008). Morphological and agronomical characterization of sweetpotato (Ipomoea batatas [L.] Lam.) germplasm collection from Tanzania. African Journal of Plant Science, 2, 077-085. ISSN 1996-0824. Retrieved from http://www.academicjournals.org/AJPS

Tumwegamire, S., Mwanga, R. O. M., Andrade, M. I., Low, J. W., Ssemakula, G. N., Laurie, S. M., ... Grüneberg, W. J. (2014). Catalogue of orange-fleshed sweetpotato varieties for Sub-Saharan Africa. Lima (Peru). International Potato Center (CIP). 2. ed. 74 p. ISBN 978-92-9060-439-6. https://dx.doi.org/10.4160/9789290604396

Vanaja, T., \& Babu, L. C. (2006). Variability in grain quality attributes of high yielding rice varieties (Oryza sativa L.) of diverse origin. Journal of Tropical Agriculture, 44(1-2), 61-63. Retrieved from http://jtropag.kau.in/index.php/ojs2/article/viewFile/153/153 
Wariboko, C., \& Ogidi, I. A. (2014). Evaluation of the performance of improved sweet potato (Ipomoea batatas L. Lam) varieties in Bayelsa state, Nigeria. African Journal of Environmental Science and Technology, 8(1), 48-53. https://doi.org/10.5897/AJEST2013.1572

Woolfe, J. A. (1992). Sweetpotato: An Untapped Food Resource. Cambridge University Press, Cambridge, UK. 363pp. Retrieved from http://books.google.com/books?id=_MWmIDzNMSYC

Yadeta, B., Belew, D., Gebreselassie, W., \& Marame, F. (2011). Variability, heritability and genetic advance in hot pepper (Capsicum annuum L.) genotypes in West Shoa, Ethiopia. American - Eurasian Journal of Agriculture and Environmental Science, 10(4), 587-592.

\section{Copyrights}

Copyright for this article is retained by the author(s), with first publication rights granted to the journal.

This is an open-access article distributed under the terms and conditions of the Creative Commons Attribution license (http://creativecommons.org/licenses/by/4.0/). 